\title{
Tumor necrosis factor alfa and interleukin 1 alfa induced phosphorylation and degradation of inhibitory kappa $B$ alpha are regulated by estradiol in endometrial cells
}

\section{Endometriyal hücrelerdeki inhibitör kappa B alfa'nın tümör nekroz faktörü ve interlökin 1 indüklenmis fosforilasyonunu estradiol ile ayarlanir}

\author{
(1D) Sefa Arlıer1,2, (D) Ümit Ali Kayışlı1, (D) Aydın Arıcı3,4 \\ 1 University of South Florida Faculty of Medicine, Department of Obstetrics and Gynecology, Tampa, USA \\ ${ }^{2}$ University of Health Sciences, Adana Numune Training and Research Hospital, Clinic of Obstetrics and Gynecology, Adana, Turkey \\ 3 Yale University Faculty of Medicine, Department of Obstetrics and Gynecology, Division of Reproductive Endocrinology and Infertility, New Haven, USA \\ ${ }^{4}$ Anadolu Medical Center, Clinic of Reproductive Endocrinology and Infertility, İstanbul, Turkey
}

\begin{abstract}
Objective: When bound to the inhibitory kappa B (ІкВ) protein, the transcription factor nuclear factor kappa B (NF-кB) remains inactively in the cytoplasm. Activated NF-кB upregulates the gene expression of many chemokines including monocyte chemoattractant protein-1 and interleukin (IL)8. We hypothesized that estrogen may regulate ІкB phosphorylation and degradation thus influencing NF-кB-dependent gene expression. Regulation of chemokines by estrogen is different in uterine endometrial cells when compared to ectopic endometrial cells of endometriosis.

Materials and Methods: We investigated the in vivo expression of ІкВ in normal endometrium and in eutopic and ectopic endometrium of women with endometriosis. We then studied in cultured endometrial cells to assess the effects of estradiol on ІкB and NF-кB function.

Results: Normal endometrium from mid-late proliferative phase revealed the strongest ІкВ immunoreactivity throughout the cycle $(\mathrm{p}<0.05)$. When compared to paired homologous eutopic endometrium, ectopic endometrium revealed significantly less immunoreactivity for IкB ( $<<0.05$ ). Moreover, estradiol induced a decrease in tumor necrosis factor-and IL-1-induced ІкB phosphorylation, and also decreased the levels of active-NF-кB ( $\mathrm{p}<0.05$ ).

Conclusion: Our results support the conclusion that one pathway for estradiol-mediated NF-кB inhibition occurs through the down-regulation of IкB phosphorylation. We propose that the estradiol-induced regulation of ІкВ and consequent reduction in active-NF-кB may affect inflammatory responses in human endometrial cells.

Keywords: Inhibitory kappa B $\alpha$, nuclear factor kappa B, estradiol, endometrium, tumor necrosis factor- $\alpha$

$\ddot{\mathrm{O} z}$

Amaç: İnhibitör kappa B (ІкB) protein bağlandığı zaman, transkripsiyon faktörü nükleer faktör kappa B (NF-кB) sitoplazmada aktive olamaz. Aktif NF-кB, monosit kemoatraktan proteini-1 ve interlökin (IL)-8 dahil olmak üzere pek çok kemokinin gen salınımını artırır. Biz östrojenin IкB- $\alpha$ fosforilasyonunu ve yıkımını düzenleyerek NF-кB'ye bağımlı genlerin salgılanmasını etkileyebileceğini varsaydık. Östrojen tarafından kemokinlerin düzenlenmesi uterus içindeki endometriyal hücrelerde, endometrioziste görülen uterus dışındaki endometriyal hücreler karşılaştırıldığında farklıdır.

Gereç ve Yöntemler: Normal endometriyum, endometrioziz de uterus içindeki ve dışındaki endometriyal hücrelerden in vivo IкB salgılanmasını araştırdık. Ayrıca estradiolün IкB ve NF-кB fonksiyonu üzerindeki etkisini değerlendirmek için endometriyal hücre kültüründe çalıştık.

Bulgular: Normal endometriyum bütün menstrual siklus boyunca orta-geç proliferatif fazda güçlü IкB immünreaktivite gözlemlendi (p<0,05). Eşleştirilmiş homolog uterus içi ve dışındaki endometriyum karşılaştırıldığında, uterus dışındaki endometriyumda anlamlı olarak daha düşük bir immünoreaktivite tespit edildi $(\mathrm{p}<0,05)$. Dahası, estradiol, tümör nekroz faktörü- $\alpha$ ve IL-1 ile indüklenen ІкB fosforilasyonunda bir düşüşe neden olmuştur ve ayrıca aktifNF-кB düzeylerini de azaltmıştır ( $<<0,05)$. Bulgularımız estradiol aracılı NF-кB inhibisyonu için bir yolun IкB fosforilasyonun aşağı regülasyonu yoluyla ortaya çıktığı sonucunu desteklemektedir.
\end{abstract}

Address for Correspondence/Yazışma Adresi: Sefa Arlıer, MD,

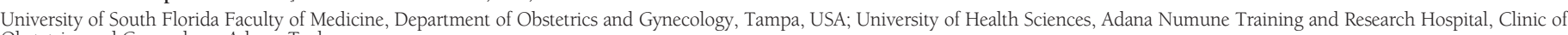
Obstetrics and Gynecology, Adana, Turkey

Phone: +90 5324861668 E-mail: sefaarlier@gmail.com ORCID ID: orcid.org/0000-0002-0019-8403

Received/Geliș Tarihi: 13.12.2017 Accepted/Kabul Tarihi: 24.01.2018

${ }^{\circledR}$ Copyright 2018 by Turkish Society of Obstetrics and Gynecology

Turkish Journal of Obstetrics and Gynecology published by Galenos Publishing House 
Sonuç: Estradiol ile indüklenen ІкB regülasyonunun ve dolayısılla aktif NF-кB'deki azalmanın insan endometriyal hücrelerindeki enflamatuvar yanıtları etkileyebileceğini varsaymaktayı.

Anahtar Kelimeler: İnhibitör kappa B $\alpha$, nükleer faktör kappa B, östrojen, endometriyum, tümör nekroz faktörü- $\alpha$

PRECIS: We have assessed that the estradiol-stimulated regulation of inhibitory kappa B $\alpha$ and subsequent decrease in nucleor factor faktör kappa B affects inflammatory reactions in human endometrial cells.

\section{Introduction}

Immunologic-endocrine interactions mediate and participate in complex physiologic processes that occur within the uterus throughout the menstrual cycle and pregnancy, and are also important to the pathophysiology of endometriosis ${ }^{(1-3)}$. One of the molecular signaling pathways that may be regulated by the endocrine system, which also participates in the regulation of inflammation, is the nuclear factor kappa B (NF-кB) signaling cascade $^{(4-6)}$. NF-KB is a transcription factor that is kept in an inactive state in the cytosol while bound to the inhibitory

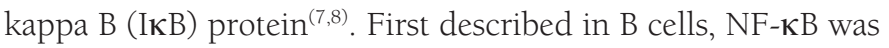
subsequently recognized as a nuclear and cytoplasmic protein that is found in multiple cell types ${ }^{(9)}$. In many cells, NF-кB positively regulates the expression of a number of genes including those of cytokines, cell adhesion molecules, complement factors, anti-apoptotic factors, and immunoreactions ${ }^{(10-12)}$. The IKB protein family is composed of $35-70 \mathrm{kDa}$ proteins that are localized in the cytoplasm and inhibit the activation of

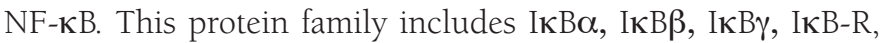
B-cell leukemia-3, p105/p50, p100/52 and the Drosophila melanogaster proteins Cactus and Relish. I $\mathrm{KB} \alpha$ and I $\mathrm{I} B \beta$ preferentially interact with NF- $\mathrm{\kappa B}$ dimers composed of proteins p65 and p50, and regulate NF-kB function by converting the heterodimer structure to a trimer that is incapable of binding DNA ${ }^{(13-15)}$. Tumor necrosis factor-alpha (TNF- $\alpha$ ) and interleukin (IL)-1 induce the phosphorylation and subsequent degradation of IкB $\alpha$. This, in turn, results in the activation and

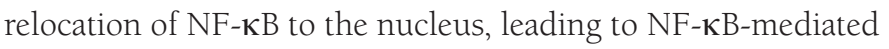
transcription of responsive genes ${ }^{(16,17)}$. Ligand binding to most, if not all, of the inflammatory cytokine receptors activates intracellular signaling molecules that engender the activation of NF-KB. Activation of such signaling molecules results in a transient activation of IКB kinase (IKK) and a transient

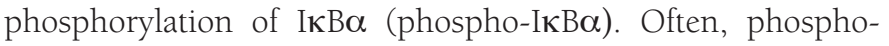
IкB $\alpha$ peaks 2-15 min after stimulation with the cytokine, and is followed by a rapid acceleration of IKB $\alpha$ degradation. Often, I $\mathrm{B} \alpha$ levels may subsequently increase in the cytosol over the following 2-6 h, in response to NF-KB-mediated upregulation of the IKB promotor ${ }^{(11,13,18)}$. Several proteins and molecules that activate NF-KB signaling have been described. IL-1 and TNF- $\alpha$ are two principal cytokines that promote I $\mathrm{K} \boldsymbol{\alpha} \alpha$ degradation and NF- $\mathrm{KB}$ activation. Although these cytokines bind to specific receptors to activate different intracellular second messengers, downstream signals merge with the activation of the same target, namely $\mathrm{IKK}^{(19-21)}$. Estrogen influences the growth, differentiation, and function of many target cells by genomic and non-genomic pathways. Although the genomic effects of estrogen are mediated via estrogen receptors (ERs) and occur over a period of hours or days, the non-genomic effects occur within minutes ${ }^{(22-24)}$. Previous studies have shown that estrogen down-regulates the expression of many cytokines such as IL1 , TNF- $\alpha$, IL- 6 and regulated-upon activation, normal T-cellexpressed and secreted (RANTES), which are regulated by NFKB in various cell types ${ }^{(25-27)}$. Previously, we have shown that estrogen inhibits monocyte chemotactic protein-l expression in human endometrial stromal cells (ESCs) ${ }^{(28)}$. Moreover, in response to estrogen, chemokine-mediated regulation of endometrial cells obtained from women with endometriosis is distinct from that observed in normal endometrial cells ${ }^{(29-31)}$. An estrogen-dependent disease, endometriosis develops outside of the uterus and is characterized by a proinflammatory peritoneal environment ${ }^{(32,33)}$. Thus, there may be differential regulation of NFKB signaling by estrogen and by cytokines such as TNF- $\alpha$ and IL-l in endometriotic cells as compared with normal endometrial cells. In endometriotic cells, there appears to be synergy between the effects of $E_{2}$ and IL-1/TNF- $\alpha$, whereas these molecules appear to function antagonistically in normal endometrial cells. We hypothesized that estrogen might regulate I $\mathrm{K} \mathrm{B} \alpha$ phosphorylation and degradation in vivo and in vitro in normal endometrium and in eutopic and ectopic endometrium of women with endometriosis, thus influencing NFKB-dependent gene expression. First, we investigated the in vivo expression of IкB $\alpha$ in normal endometrium and in eutopic and ectopic endometrium of women with endometriosis. We then investigated the modulation of I $\mathrm{I} B \alpha$ by $\mathrm{E}_{2}$ in TNF- $\alpha$ - and IL-l $\alpha$-treated endometrial stromal and glandular cells, in vitro, using Western blot analysis and immunocytochemistry.

\section{Materials and Methods}

\section{Tissue collection}

Endometrial tissues were obtained from human uteri after hysterectomy conducted for benign diseases excluding endometrial disease, and from endometrial biopsies. Approval for this study was granted by the Human Investigation Committee of Yale University (HIC\#22334) and written informed consent was obtained from each patient prior to surgery. The mean age of the patients was 36 years (range, 30-45 years).

For immunohistochemistry, normal cyclic endometrium $(\mathrm{n}=12)$ of women without endometriosis, and eutopic and ectopic endometrium pairs of women with endometriosis $(n=6)$ were 
collected, and paraffin blocks were routinely prepared and cut at 5-7 mm. For the endometrial cells used in culture, the diagnoses of the patients were leiomyomata uteri or voluntary sterilization by tubal ligation $(n=5)$. The day of the menstrual cycle was established from the patient's menstrual history and was verified through histologic examination of the endometrium. The tissues were placed in Hank's balanced salt solution and transported to the laboratory for separation and culture of endometrial stromal and glandular cells. Each experimental setup was repeated on at least three occasions using cells obtained from different patients.

\section{Isolation and culture of human endometrial stromal and glandular cells}

Endometrial tissues were separated and conserved in a monolayer culture, as described previously ${ }^{(34)}$. The isolated endometrial cells were separated by filtration through a wire sieve (73 $\mu \mathrm{m}$ diameter pore, Sigma). The endometrial glands (largely undispersed) were retained by the sieve, whereas the dispersed stromal cells passed through the sieve into the filtrate. The stromal cells were plated in plastic flasks $\left(75 \mathrm{~cm}^{2}\right.$, Falcon, Franklin Lakes, NJ), maintained at $37{ }^{\circ} \mathrm{C}$ in a humidified atmosphere $\left(5 \% \mathrm{CO}_{2}\right.$ in air), and allowed to replicate to confluence. Thereafter, the stromal cells were passed by standard methods of trypsinization, plated in culture dishes $(100 \mathrm{~mm}$ diameter), and allowed to replicate to confluence. ESCs after the first passage were characterized as described previously ${ }^{(34)}$ and were found to contain 0-7\% epithelial cells, no detectable endothelial cells, and $0.2 \%$ macrophages. Experiments were commenced 1-3 days after the cells reached confluence. The confluent cells were treated with serum-free, phenol red-free media for $24 \mathrm{~h}$ before treatment with test agents. Stromal cells reached confluence in 7-10 days.

Experiments with glandular cells were performed using a welldifferentiated endometrial adenocarcinoma cell line (Ishikawa cell) provided to us by Dr. R. Hochberg (Department of Obstetrics and Gynecology, Yale University, New Haven, CT) from a frozen stock. Thawed cells were maintained in T75 flasks (BD Biosciences, Franklin Lakes, NJ) until passage. The cells were treated with serum-free phenol red-free media for 24 $\mathrm{h}$ before treatment with test agents. Cells were treated with $\mathrm{E}_{2}$ (Sigma) for 3-90 min and immunocytochemistry and Western blot analysis were performed as described.

\section{Immunohistochemistry and immunocytochemistry}

Endometrial tissue sections from normal, eutopic, and ectopic endometrium were deparaffinized and washed with phosphate buffered saline (PBS). Thereafter, sections were twice microwaved in citric acid buffer (0.1 M, pH: 6) and thoroughly rinsed in PBS. The same steps used for immunocytochemistry (described below) were followed. ESCs were grown to preconfluence on four-chamber slides. Following treatment, the chamber slides were fixed in 4\% paraformaldehyde for $20 \mathrm{~min}$. After several washes with distilled water and then with PBS
( $\mathrm{pH}$ 7.4) (three times $10 \mathrm{~min}$ each), endogenous peroxidase activity was quenched by $3 \% \mathrm{H}_{2} \mathrm{O}_{2}\left(0.6 \mathrm{~mL} \mathrm{H}_{2} \mathrm{O}_{2}\right.$ and 5.4 $\mathrm{mL}$ methanol) for $10 \mathrm{~min}$ and the slides were then rinsed in PBS-tween. Slides were then incubated with rabbit anti-IкB $\alpha$ polyclonal antibody (Cell signaling Technology, Beverly, MA) for $60 \mathrm{~min}$ at room temperature. In negative control slides, normal rabbit immunoglobulin G (IgG) was used as a control instead of primary antibody. After several rinses in PBS, goat biotinylated anti-rabbit IgG (Vector Laboratories, Burlingame, CA) was applied for $30 \mathrm{~min}$. After several rinses with PBS, the slides were incubated with streptavidin-peroxidase complex for $30 \mathrm{~min}$ (Vector Laboratories). The slides were then rinsed several times in PBS and incubated with 3-amino-9-ethyl-carbazole (Vector Laboratories) for $10 \mathrm{~min}$. The slides were lightly counterstained with hematoxylin prior to permanent mounting. Immunocytochemical staining intensity was ranked between 0 (absent) to 3 (most intense). For each slide, an HSCORE value was derived by summing the percentages of cell staining at each intensity multiplied by the weighted intensity of the staining [HSCORE $=\Sigma \mathrm{P}_{i}(i+1)$, where $i$ is the intensity scores and $\mathrm{P}_{i}$ is the corresponding percentage of the cells]. In each slide, five randomly selected areas were assessed microscopically using $50 \times$ magnification. Two investigators who were blinded to the treatments analyzed each slide for intensity. The averages for the scores of both investigators are presented.

\section{IkBa and phospho-IkBa Western blot analysis}

Total protein from endometrial cells was extracted in a lysis buffer composed of $50 \mathrm{mM}$ hydroxyethyl piperazineethanesulfonic, pH: 7.4; $150 \mathrm{mM} \mathrm{NaCl} ; 10 \%$ glycerol, $1 \%$ Triton X-100, $1.5 \mathrm{mM} \mathrm{MgCl}-6 \mathrm{H}_{2} \mathrm{O} ; 1 \mathrm{mM}$ EGTA; $100 \mathrm{mM} \mathrm{NaF}, 10 \mathrm{mM}$ sodium pyrophosphate and protease inhibitors, $1 \mathrm{mM}$ $\mathrm{Na}_{3} \mathrm{VO}_{4}, 10 \mu \mathrm{g} / \mathrm{mL}$ leupeptin, $10 \mu \mathrm{g} / \mathrm{mL}$ aprotinin; and $4 \mathrm{mM}$ phenylmethylsulfonyl fluoride. The protein concentration was determined by a detergent-compatible protein assay (Bio-Rad Laboratories, Hercules, CA). Protein lysates $(20 \mu \mathrm{g})$ were loaded and separated using sodium dodecyl sulfate-polyacrylamide gel electrophoresis with 10\% Tris-Hydrogen chloride Ready Gels (Bio-Rad Laboratories) and electroblotted onto nitrocellulose membrane (Bio-Rad Laboratories). Equal loading of proteins in each lane was confirmed by staining the membrane with Ponceau 2S (Sigma). The membrane was incubated with 5\% nonfat dry milk in tris-buffered saline-tween (TBS-T) buffer (0.05\% tween-20 in PBS, pH 7.4) for $1 \mathrm{~h}$ to reduce nonspecific binding of antibody. The membrane was probed with rabbit

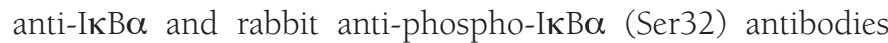
(Cell Signaling Technology) overnight to quantitate total and phospho-IкB $\alpha$ forms. After washing with TBS-T, blots were incubated for $1 \mathrm{~h}$ with peroxidase labeled anti-rabbit $\operatorname{IgG}$ (Vector Laboratories) diluted at 1:10000. Membranes were washed with TBS-T and the immunoblots were developed using chemiluminescent kit following the manufacturer's instructions. (NEN Life Science, Boston, MA). The signal was normalized by dividing the arbitrary densitometry units for phospho-IкB $\alpha$ to the 
amount of total IKB $\alpha$ for each band. The signals were quantified by using a laser densitometer (Molecular Dynamics, Sunnyvale, CA) to analyze the autoradiographic bands.

\section{Preparation of nuclear extracts and the active-NF-кB assay}

To quantify the amount of active NF- $\mathrm{KB}$, which binds to NFkB response element sites on gene promotors, an enzyme-linked immunosorbent (ELISA) plate covered with NF- $\mathrm{kB}$ binding consensus sequence oligonucleotide (5'-GGGACTTTCC-3') was used in combination with nuclear extracts from our cultured cells. Two different primary antibodies against NF- $\kappa B$ each recognize either an epitope on p65 or on p50 that is accessible only after dissociation of $\mathrm{I} \kappa \mathrm{B}$ from NF- $\mathrm{KB}$, indicating the activation of cytoplasmic NF- $\kappa$ B. An horseradish peroxidaseconjugated secondary antibody provides a colorimetric readout that is quantitated using spectrophotometry $(450 \mathrm{~nm})$. As a positive control for activated NF- $\kappa B$, nuclear extracts from HeLA cells were used. To monitor the specificity of the assay, both wild type and mutated consensus oligonucleotides were employed in each reaction. Nuclear extracts from endometrial cells grown to confluence in $60 \mathrm{~mm}$ plates were obtained using a nuclear extraction kit (Active Motif, Carlsbad, CA). Briefly, cells were washed with ice-cold PBS and protease/phosphatase inhibitors, removed from the dish by scraping with a cell lifter and transferred to pre-chilled tubes. Cell suspensions were centrifuged at $4{ }^{\circ} \mathrm{C}$ for $5 \mathrm{~min}$ at $500 \mathrm{rpm}$. Pellets were resuspended in hypotonic buffer and incubated for $15 \mathrm{~min}$ on ice, detergent was added, and the cells were centrifuged at 4 ${ }^{\circ} \mathrm{C}$ for 30 seconds at $14.000 \times \mathrm{g}$. The pellet was resuspended in a lysis buffer and incubated for $30 \mathrm{~min}$ on ice on a rocking platform. The suspension was centrifuged at $4{ }^{\circ} \mathrm{C}$ for $10 \mathrm{~min}$ at $14.000 \times \mathrm{g}$ and the supernatant (nuclear fraction) was aliquoted and frozen at $-80{ }^{\circ} \mathrm{C}$. Nuclear fractions were quantitated using a Coomassie protein assay (Pierce; Rockford, IL) as per the manufacturer's protocol. Four micrograms of nuclear extract sample were loaded into each well and assayed according to the manufacturer's directions (Active Motif) using a microplate reader. Quantification of the NF- $\mathrm{kB}$ p50 subunit was expressed as mean absorbance $(\lambda)$ per sample.

\section{Statistical Analysis}

IкB $\alpha$ immunocytochemistry scores and Western blot results were normally distributed as assessed using the KolmogorovSmirnov test. Analysis of variance (ANOVA) and post hoc Tukey test for pair-wise comparisons were used in statistical analysis. $\mathrm{p}<0.05$ was considered to be significant. Statistical calculations were performed using Sigma stat for Windows, version 2.0 (Jandel Scientific Corporation, San Rafael, CA).

\section{Results}

Expression of IкB $\alpha$ in normal endometrium, and in eutopic and ectopic endometrium from women with endometriosis

Eutopic endometrial stromal and glandular cells from women without endometriosis express immunoreactive IкB $\alpha$ (Figure
1). The antibody used for immunohistochemistry recognizes both phosphorylated and unphosphorylated forms of IKB $\alpha$. In normal endometrium, glandular cells reveal stronger immunoreactivity for IKB $\alpha$ compared with stromal cells throughout the menstrual cycle. Stronger immunoreactivity was detected in samples of mid-late proliferative endometrium compared with late secretory and early proliferative phase samples $(\mathrm{p}<0.05)$ (Figure 1, Table 1). When proliferative phase and secretory phase immunoreactivity for IKB were compared, the proliferative phase showed a trend for stronger immunoreactivity although this difference did not reach statistical significance. Eutopic and ectopic endometrium from women with endometriosis also revealed immunoreactivity for IкB $\alpha$. When the eutopic endometrium from women with endometriosis was compared with the endometrium of women without endometriosis, no significant difference was observed in staining intensity, although eutopic endometrial cells of women with endometriosis showed a trend towards decreased immunoreactivity for $\operatorname{I\kappa B} \alpha(\mathrm{p}=0.1)$ (Figure 1, Table 2). On the other hand, when compared with eutopic endometrium, homologous ectopic endometrium revealed significantly less immunoreactivity for IאB $\alpha(\mathrm{p}<0.05)$ (Figure 1, Table 2).

Estradiol-regulated expression of ІкB in endometrial cells as assessed using immunocytochemistry

ESCs grown on four-chamber slides were placed in serum-free, phenol red-free media for $24 \mathrm{~h}$, and were then treated for $15 \mathrm{~min}$ with fresh serum-free, phenol red-free media as control, with TNF- $\alpha(2 \mathrm{ng} / \mathrm{mL})$, or estradiol $\left(10^{-8} \mathrm{M}\right)$ combined with TNF- $\alpha$ $(2 \mathrm{ng} / \mathrm{mL}$ ) for $15 \mathrm{~min}$. Slides were stained with rabbit anti-IкB $\alpha$ antibody. Cells treated with TNF- $\alpha$ alone showed a very weak immunoreactivity for ІкB $\alpha$ when compared with the control (Figure 2a, b). On the other hand, cells treated with TNF- $\alpha$ combined with $\mathrm{E}_{2}$ displayed a stronger IKB $\alpha$ immunoreactivity than those treated with TNF- $\alpha$ alone $(\mathrm{p}<0.05)$ (Figure 2b, $\mathrm{c}$ ). We also compared cells maintained for $24 \mathrm{~h}$ in serum-free phenol red-free media for $24 \mathrm{~h}$, with or without $\mathrm{E}_{2}\left(10^{-8} \mathrm{M}\right)$, followed by TNF- $\alpha(2 \mathrm{ng} / \mathrm{mL})$ treatment for an additional 15 min. TNF- $\alpha-$ stimulated I $\mathrm{B} \alpha$ immunoreactivity was stronger in cells pre-treated with $\mathrm{E}_{2}$ compared with those pre-treated with serum-free media alone $(\mathrm{p}<0.05)$ (Figure $2 \mathrm{~d}-\mathrm{f})$.

Regulation of ІкВ $\alpha$ expression and phosphorylation in endometrial cells as assessed using Western blot analysis

We sought to understand whether the increased ІкB $\mathrm{\alpha}$ immunoreactivity observed in cells treated with both TNF- $\alpha$ and $\mathrm{E}_{2}$ was associated with a phosphorylation and subsequent degradation of IкB $\alpha$. After $24 \mathrm{~h}$ of incubation with serum-free, phenol red-free media, ESCs were treated with media alone (control), $\mathrm{E}_{2} 10^{-8} \mathrm{M}$ alone, TNF- $\alpha 2 \mathrm{ng} / \mathrm{mL}$ alone, or with $\mathrm{E}_{2}$ $10^{-8} \mathrm{M}$ combined with TNF- $\alpha 2 \mathrm{ng} / \mathrm{mL}$ for 3, 6, 12, 30, and $60 \mathrm{~min}$. Total protein was extracted and levels of total ІкВ $\alpha$ and phospho-IкB $\alpha$ were measured using Western blot analysis. Control and $\mathrm{E}_{2}$-treated cells showed similar levels of IкB $\alpha$ 
throughout the treatment period. On the other hand, treatment with TNF- $\alpha$ resulted in a time-dependent decrease in I $\mathrm{I} B \alpha$ levels compared with the control. Moreover, this treatment caused a time-dependent increase in phospho-ІкB $\alpha$ levels with a peak between 6 and 12 min of treatment. Meanwhile,

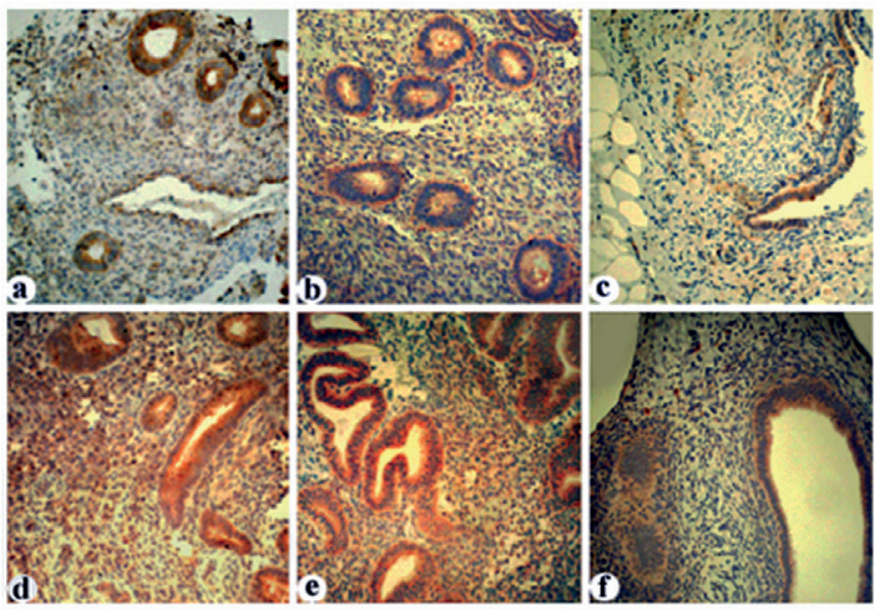

Figure 1. Inhibitory kappa B (ІкВ $\alpha$ ) immunoreactivity in human normal (a, d), eutopic (b, e) and ectopic (c, f) endometrial tissues. IкB $\alpha$ immunoreactivity in proliferative $(\mathrm{a}, \mathrm{c})$ and secretory phase $(d, f)$ tissue samples are seen. Stronger immunoreactivity in endometrial glands and stromal cells in normal endometrium are observed when compared with ectopic endometrial and stromal cells. (a-f x40)

Table 1. Inhibitory kappa B immunoreactivity in various cell types of human endometrium throughout the cycle. Early proliferative $(n=2)$, late proliferative $(n=4)$, early secretory $(n=4)$ and late secretory $(n=2)$

$\begin{array}{lllll} & \begin{array}{l}\text { Early } \\ \text { proliferative }\end{array} & \begin{array}{l}\text { Late } \\ \text { proliferative }\end{array} & \begin{array}{l}\text { Early } \\ \text { secretory }\end{array} & \begin{array}{l}\text { Late } \\ \text { secretory }\end{array} \\ \begin{array}{l}\text { Glandular } \\ \text { cells }\end{array} & + & ++/++ & ++ & +/++ \\ \begin{array}{l}\text { Stromal } \\ \text { cells }\end{array} & -/+ & ++ & +/+ & + \\ \begin{array}{l}\text { Endothelial } \\ \text { cells }\end{array} & + & ++ & +/+ & +/++ \\ & & & & \end{array}$

Table 2. Inhibitory kappa B immunoreactivity in various cell types of normal, eutopic and ectopic endometrium. Menstrual cycle matched normal endometrium $(n=6)$, eutopic and ectopic pairs of endometriotic endometrium samples $(n=6)$

$\begin{array}{llll} & \begin{array}{l}\text { Normal } \\ \text { endometrium }\end{array} & \begin{array}{l}\text { Eutopic } \\ \text { endometrium }\end{array} & \begin{array}{l}\text { Ectopic } \\ \text { endometrium }\end{array} \\ \begin{array}{llll}\text { Glandular } \\ \text { cells }\end{array} & ++/+++ & +/++++ & + \\ \begin{array}{l}\text { Stromal cells } \\ \text { Endothelial }\end{array} & ++++ & -/+/++ & -/+ \\ \text { cells } & + & +/++ & -/+\end{array}$

$\mathrm{E}_{2}$ combined with TNF- $\alpha$ treatment showed markedly higher

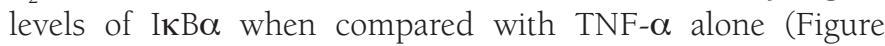
$3)$. When groups were compared in terms of phospho-IкB $\alpha$ levels, control and $\mathrm{E}_{2}$-treated cells revealed the lowest levels of phospho-IкB $\alpha$ throughout the treatment periods. However, in cells treated with TNF- $\alpha$, co-treatment with $\mathrm{E}_{2}$ induced higher

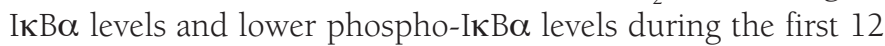
minutes of treatments ( $\mathrm{p}<0.05$ ) (Figure 3). Following $60 \mathrm{~min}$

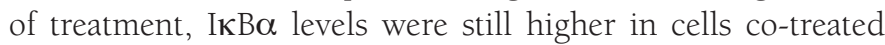
with $\mathrm{E}_{2}$ compared with cells treated with TNF- $\alpha$ alone (Figure $4 a$ ). Interestingly, in glandular cells, longer treatment with $E_{2}$ with TNF- $\alpha$ (90 min) resulted in a significantly higher level of IкB $\alpha$ compared with other treatments, including the control

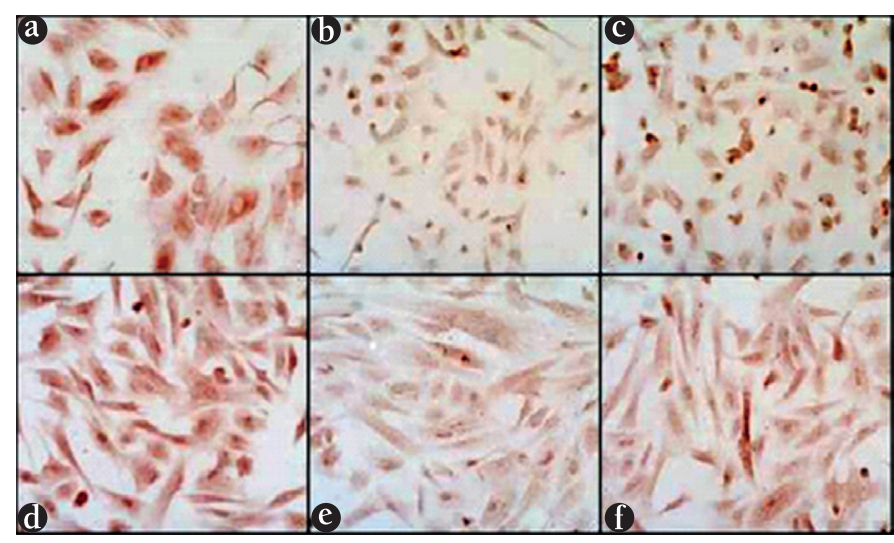

Figure 2. Inhibitory kappa $\mathrm{B}(\mathrm{I} \kappa \mathrm{B} \alpha)$ immunoreactivity in endometrial stromal cells treated with estradiol and tumor necrosis factor-alpha (TNF- $\alpha$.) Endometrial stromal cells were treated for 12 min with vehicle (control) (a), TNF- $\alpha$ ( $2 \mathrm{ng} / \mathrm{mL})(\mathrm{b})$, or estradiol (10 $\left.{ }^{8} \mathrm{M}\right)$ combined with TNF- $\alpha$ (c), and were immunostained for IкB $\alpha$. Cells treated with estradiol combined with TNF- $\alpha$ showed stronger immunoreactivity for IкB $\alpha$ than cells treated with TNF- $\alpha$ alone. Endometrial stromal cells were pretreated with vehicle (control) (d, e) or estradiol (f) for $24 \mathrm{~h}$ prior to stimulation with TNF- $\alpha$ (e, f) for $15 \mathrm{~min}$. Following stimulation with TNF- $\alpha$ cells pretreated with estradiol for $24 \mathrm{~h}$ (f) showed stronger immunoreactivity for ІкВ $\alpha$ than cells that were not pretreated with estradiol (e)

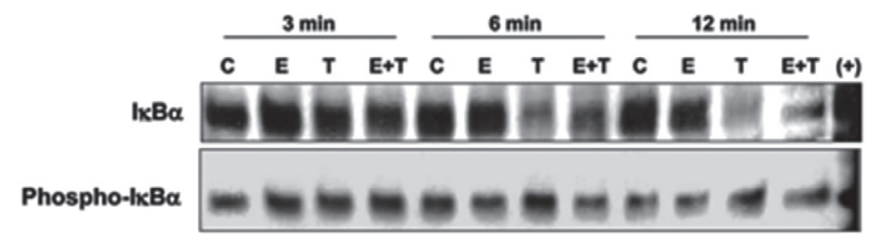

Figure 3. Regulation of inhibitory kappa B (ІкВ $\alpha$ ) in endometrial stromal cells by estradiol and tumor necrosis factor-alpha (TNF- $\alpha$ ). Endometrial stromal cells treated with estradiol $\left(E_{2} ; 10^{-8} \mathrm{M}\right)$, TNF- $\alpha(\mathrm{mg} / \mathrm{mL})$ alone, or estradiol with TNF- $\alpha\left(\mathrm{E}_{2}+\mathrm{T}\right)$, or vehicle (C; control) were analyzed for $\mathrm{I \kappa B} \alpha$ and its phosphorylated form following 3-12 min treatment. Estradiol treatment suppressed partially the TNF- $\alpha$-induced $\operatorname{~} \kappa \mathrm{B} \alpha$ degradation at 6 and $12 \mathrm{~min}$. (+: positive control from TNF- $\alpha$-induced HeLa cell extracts)

Phosphorylation of $I \kappa B \alpha$ : Inhibitory kappa B alpha 
group (Figure 4b). Glandular cells treated with $\mathrm{E}_{2}$ plus TNF- $\alpha$ demonstrated higher phospho-IкB $\alpha$ levels when compared with cells treated with TNF- $\alpha$ alone $(\mathrm{p}<0.05)$.

As observed using immunoblotting, the effect of $E_{2}$ on IKB $\alpha$ was more pronounced when glandular cells were pre-treated with $\mathrm{E}_{2}$ for $24 \mathrm{~h}$ prior to TNF- $\alpha$ treatment (Figure 5). To determine whether the effect of $E_{2}$ on I $\kappa \alpha \alpha$ phosphorylation was specific to the TNF- $\alpha$ signaling cascade, we also explored the effect of estrogen on IL-l $\alpha$-mediated activation of NF- $\mathrm{\kappa B}$. Cells were treated with $\mathrm{E}_{2}\left(10^{-8} \mathrm{M}\right)$, IL-1 $\alpha(2 \mathrm{ng} / \mathrm{mL}), \mathrm{E}_{2}$ plus IL-l $\alpha$, or

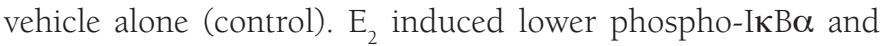
higher IкB $\alpha$ levels in IL-1 $\alpha$-treated cells as compared with cells treated with IL-1 $\alpha$ alone (Figure 6).
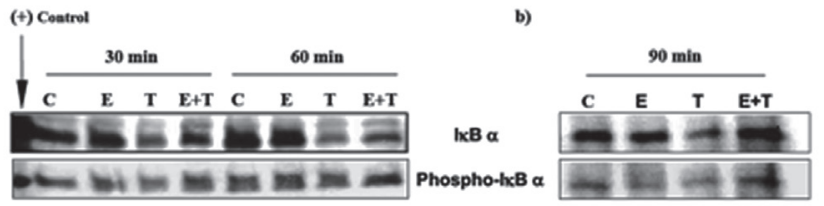

Figure 4. Regulation of inhibitory kappa B-alpha (ІкВ $\alpha$ ) in endometrial stromal cells by estradiol and tumor necrosis factoralpha (TNF- $\alpha$ ). Endometrial stromal cells were treated with estradiol $\left(\mathrm{E}_{2}\right) ; 10^{-8} \mathrm{M}, \mathrm{TNF}-\alpha(\mathrm{T} ; 1 \mathrm{mg} / \mathrm{mL})$, estradiol in addition to TNF- $\alpha\left(E_{2}+T\right)$, or vehicle (C; control) for 30-60 min. Estradiol has a partial opposing effect on TNF- $\alpha$-induced ІкB $\alpha$ phosphorylation and degradation at both time points (a). Endometrial glandular cells were treated in a similar manner for $90 \mathrm{~min}$, and similar effects were observed (b)

Phospho-I $\mathrm{B} \alpha$ : Phosphorylation of inhibitory kappa B-alpha

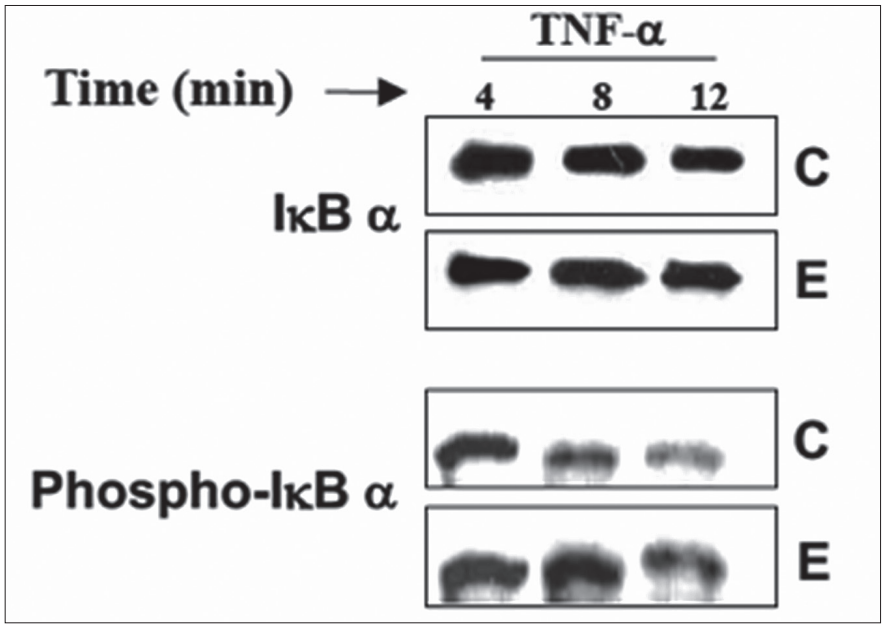

Figure 5. Regulation of inhibitory kappa B alpha (ІкB $\alpha$ ) in endometrial glandular cells by estradiol and tumor necrosis factoralpha (TNF- $\alpha)$. Endometrial glandular cells were pre-treated with estradiol $\left(\mathrm{E}_{2}\right) ; 10^{-8} \mathrm{M}$, or vehicle ( $\mathrm{C}$; control) for $24 \mathrm{~h}$ prior to treatment with TNF- $\alpha$ (1 mg/mL) for $4-12 \mathrm{~min} . \mathrm{E}_{2}$ pre-treatment inhibited ІкВ $\alpha$ degradation compared with control

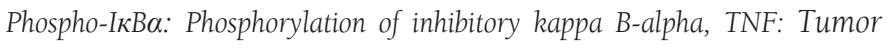
necrosis factor-alpha
Regulation of TNF- $\alpha$ - and IL- $1 \alpha$-induced activation of NFкB by $\mathrm{E}_{2}$ as assessed using an NF-кB binding assay

To understand whether the TNF- $\alpha$ - and IL-1 $\alpha$-induced IкB $\alpha$ levels in $E_{2}$-treated cells was associated with a decrease in free NF-KB, ESCs were treated with serum-free, phenol red-free media as control, and with $\mathrm{E}_{2}\left(10^{-8} \mathrm{M}\right)$ alone, TNF- $\alpha$ (2 ng/ $\mathrm{mL})$ alone, IL-l $\alpha(2 \mathrm{ng} / \mathrm{mL})$ alone, $\mathrm{E}_{2}$ combined with TNF- $\alpha$

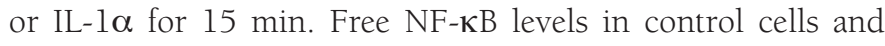
$\mathrm{E}_{2}$-treated cells were lower than those in TNF- $\alpha$ - and IL- $1 \alpha$ treated cells. On the other hand, $E_{2}$ decreased the TNF- $\alpha-$ and IL- $\alpha$-induced free NF-KB levels as compared with cells treated with TNF- $\alpha$ alone or IL-l $\alpha$ alone (Figure 7).

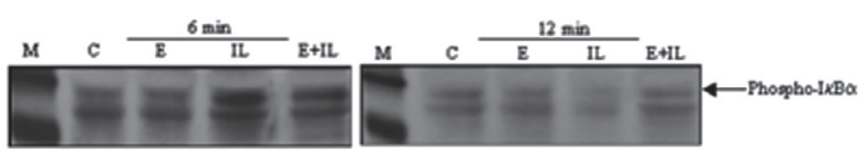

Figure 6. Regulation of inhibitory kappa B (ІкB $\alpha$ ) in endometrial stromal cells by estradiol and interleukin (IL)- $1 \alpha$. Endometrial stromal cells were treated for 6 and 12 min with estradiol $\left(E_{2}\right) ; 10^{-8}$

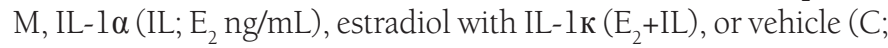
control) and were analyzed for phospho-ІкВ $\alpha$. Estradiol treatment suppressed IL-1 $\alpha$-induced ІкB $\alpha$ degradation at 6 and 12 min

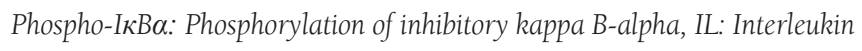

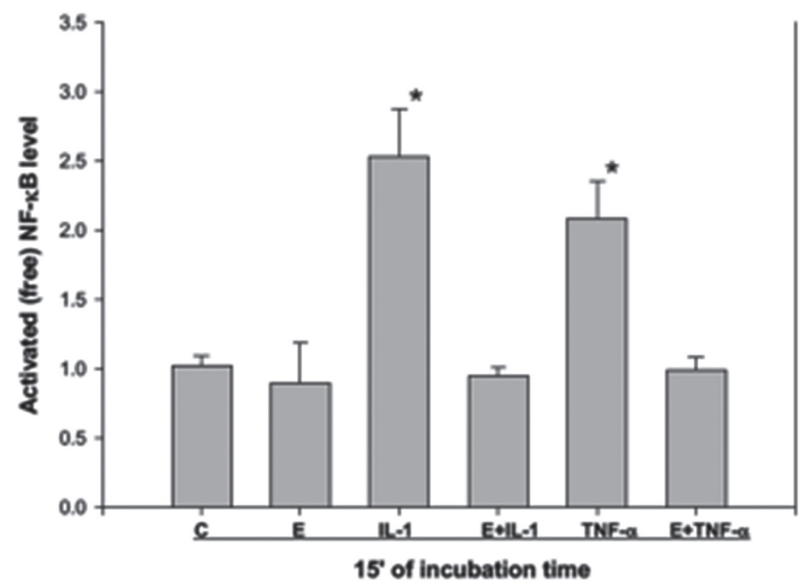

Figure 7. Regulation of active nuclear factor kappa B level in endometrial stromal cells by estradiol. The amount of activated NF-KB in endometrial stromal cells after 15 min of treatment with estradiol $\left(\mathrm{E}_{2}\right) ; 10^{-8} \mathrm{M}$, interleukin (IL)- $1 \alpha$ (IL-1; $2 \mathrm{ng} / \mathrm{mL}$ ) and $\mathrm{E}_{2}+\mathrm{IL}-1\left(10^{-8} \mathrm{M}\right.$ and $\left.2 \mathrm{ng} / \mathrm{mL}\right)$, tumor necrosis factor-alpha (TNF- $\alpha$ ) (TNF; $2 \mathrm{ng} / \mathrm{mL})$ and $\mathrm{E}_{2}+\mathrm{TNF}\left(10^{-8} \mathrm{M}\right.$ and $\left.2 \mathrm{ng} / \mathrm{mL}\right)$ were compared with control cells. Experiments were repeated on three occasions with similar results and a representative graph from one experiment is presented

NF-кB: Nuclear factor kappa B, IL: Interleukin, TNF- $\alpha$ : Tumor necrosis factor-alpha 


\section{Discussion}

Steroid hormones classically bind to cognate nuclear receptors to regulate target gene expression ${ }^{(35)}$. Estrogen takes part in cell and tissue regulation at many stages of human life. In addition to the reproductive tract of women, other systems such as the skeletal and nervous systems are important targets for estrogen action ${ }^{(36,37)}$. Estrogen mainly affects cells through the genomic pathway ${ }^{(38)}$. Estrogen actions may also result from non-genomic activity, possibly related to the cell type, receptor type, and the presence of intracellular co-factors that may interact with typical or atypical ERs. Non-genomic effects occur within minutes and appear to include cell membrane-dependent signaling mechanisms such as the nitric oxide cascade, stimulation of p38mitogen-activated protein kinase, or phosphorylation of protein kinase $\mathrm{B}$, among others ${ }^{(39-42)}$. In contrast, long-term effects of estrogen, namely genomic effects, arise over hours or longer and are directed in part by DNA estrogen response elements ${ }^{(43)}$. Some biologic processes can also play a role in both genomic and nongenomic pathways. A previous study showed that the lipopolysaccharide-stimulated activation of NF-KB was reduced by cell-impermeable $\mathrm{E}_{2}$-bovine serum albumin in mouse bone marrow-derived macrophage cultures in both genomic and nongenomic pathways ${ }^{(44)}$. Eutopic and ectopic endometrium undergoes cycle-dependent changes predominantly controlled by estrogen and progesterone in their implantation site $e^{45-}$ 47). The present study is focused on the anti-inflammatory effects of estrogen, assessing $І$ І $\mathrm{B} \alpha$ phosphorylation and NF- $\kappa \mathrm{B}$ activation in endometrial and endometriotic cells. In vitro and in vivo studies indicate that NF-KB-mediated gene transcription stimulates inflammation, invasion, angiogenesis, and cell proliferation, and reduces apoptosis of endometriotic cells. Excessive activation of NF-KB has been confirmed in endometriotic implants and peritoneal macrophages of patients with endometriosis ${ }^{(48,49)}$. In inflammatory tissue, an increase in TNF- $\alpha$ is often the first step in the cascade, followed by increases in the expression of various chemokines and the recruitment of leukocytes ${ }^{(27,50-53)}$. Previous studies have shown that, when bound to their receptors, TNF- $\alpha$ and IL-1 increase I $\mathrm{KB} \alpha$ phosphorylation, degradation, and eventually NF- $\kappa B$ activation, which results in increased inflammatory cells and expression of several inflammatory cytokines and chemokines ${ }^{(27,54,55)}$.

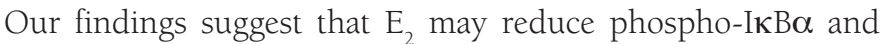
therefore decrease its degradation in endometrial cells. In this way, estrogen may block NF-KB transport into the nucleus and attenuate the inflammatory response. To our knowledge, this is the first study to report IKB $\alpha$ regulation by estrogen in endometrial stromal and glandular cells. It is possible that this increase arises from effects on the transcriptional or translational machinery, because a previous study has shown that $\mathrm{E}_{2}$ has a down-regulatory effect on I $\mathrm{I} B \alpha$ at the mRNA level in phorbol ester-induced HeLa cells ${ }^{(56)}$. Alternatively, a previous study performed using MCF-7 cells suggested that this increase was related to the increase of p105 protein level ${ }^{(57)}$. On the other hand, another research group showed that estrogen treatment decreased liver IкB mRNA and protein expression and also increased ethanol-induced liver NF-KB levels and TNF- $\alpha$ expression ${ }^{(58)}$. These disparate findings are likely to be related to the cell-specific effects of estrogen and merit further analysis. Several cytokines participate in NF- $\mathrm{KB}$ activation. In addition to TNF- $\alpha$, IL- $1 \alpha$ also regulates IкB $\alpha$ levels in the cytosol. The similar effects on IKB $\alpha$ levels by $E_{2}$ co-treatment with TNF- $\alpha$ and with IL- $1 \alpha$, compared with treatments with TNF- $\alpha$ or IL$1 \alpha$ alone, indicate that the effect of $E_{2}$ is not specific for the TNF- $\alpha$ signaling cascade. IL- $1 \alpha$ initiates an alternate cascade for I $\kappa \mathrm{B} \alpha$-related NF- $\kappa \mathrm{B}$ activation to that of TNF- $\alpha$. Furthermore, because both signaling pathways merge on IKK activation, the effect of estrogen may be on IKK activation or on subsequent steps. Bulun et al. ${ }^{(59)}$ studied NF-KB $\alpha$ and IкB $\alpha$ expression in human fetal membranes and decidua at preterm and term gestation. The authors observed a marked increase in the nuclear localization of p65 and in the IкB $\alpha$ immunoreactivity in tissues obtained at term compared with tissues delivered preterm, suggesting a role for p65 in the regulation of parturition-related gene transcription in the decidua ${ }^{(59)}$. Our in vivo results show an increase in I $\mathrm{K} B \alpha$ levels from early proliferative to the late proliferative phase, and suggest direct or indirect estrogenic regulation of IKB $\alpha$ in human endometrial cells. On the other hand, persistently low levels of IкB $\alpha$ immunoreactivity in ectopic endometrial cells are likely to be related to the increased local inflammation observed in endometriosis and may contribute to the increased inflammatory cytokine levels in the peritoneal cavity of women with endometriosis ${ }^{(60,61)}$. Endometriosis is an estrogen-dependent disease and implants of endometriosis have sufficient enzymes for the local production of estrogen ${ }^{(54,59,62-64)}$. The low levels of I $\mathrm{B} \alpha$ in ectopic endometrial cells suggest that the signaling effects of estrogen on IкB $\alpha$ may function similarly to those observed in eutopic endometrium. It seems that there is a lack of the inhibitory effect of $E_{2}$ on cytokine-induced Iк $\mathrm{B} \alpha$ phosphorylation in ectopic endometrium. Supporting this hypothesis, a recent study has shown that $E_{2}$ increases phospho-IкB levels, and more interestingly, induces higher IL-8 levels in endometriotic cells when compared with eutopic endometrium ${ }^{(65)}$. Similarly, Akoum et al. ${ }^{(66)}$ showed that $\mathrm{E}_{2}$ and IL-1 $\beta$ had synergistic effects on the expression of RANTES, revealing that $E_{2}$ enhanced the mRNA stability of RANTES, and IL-1 $\beta$ increased its transcription. A recent study reported the

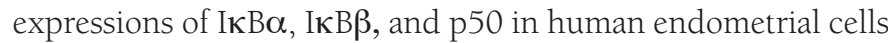
throughout the menstrual cycle ${ }^{(67)}$. Expression of these inhibitory proteins decreased significantly during the mid-secretory phase of the cycle. The study detected maximal immunoreactivity for Ік $\mathrm{B} \alpha$ during the late proliferative phase, consistent with our findings. Another study showed an increase in IкB $\alpha$ mRNA levels in the pre-menstrual endometrium, suggesting activation of NF- $\kappa B$ during this phase or alternate regulation of $I \kappa B \alpha$ expression ${ }^{(68)}$. Our results support the findings of this study because activation of NF- $\mathrm{KB}$ requires I $\mathrm{B} \alpha$ phosphorylation 
and degradation, low levels of $\mathrm{I} \mathrm{B} \boldsymbol{\alpha} \alpha$ protein would stimulate high level of IкB $\alpha$ mRNA during the pre-menstrual phase to replenish degraded IKB protein. One reason for the inhibitory effect of estrogen on chemokine expression may be related to decreased IкB $\alpha$ degradation. As a consequence, estrogen may decrease the amount of free-NF- $\mathrm{\kappa B}$ in the cytosol, and therefore decrease the level of activation. Recently, we showed that the presence of ligand ERs suppressed free-NF- $\mathrm{\kappa B}$ subunits (both p65 and p50) binding to NF-KB response element, ${ }^{(26)}$ suggesting a second mechanism for estrogen-dependent inhibition of NF-KB-mediated gene activation. ERs in ESCs inhibited DNA

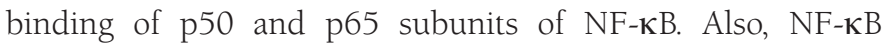
activation significantly reduced estrogen responsiveness of ERalpha-transfected ESCs, but p50 did not impair ER-alpha DNA binding, suggesting possible indirect mechanisms for this type of interaction ${ }^{(26)}$.

\section{Study Limitations}

There were some limitations in the present study. This study presented a limitation with regard to experimental circumstances. These results also need to be assessed under in vivo conditions.

\section{Conclusion}

Our results support the hypothesis that $E_{2}$ inhibits NFKB activation through the down-regulation of I $\mathrm{I} B \alpha$ phosphorylation and consequent reduction of free NF- $\mathrm{\kappa B}$ in the cytosol. These results demonstrate that the regulation of I $\mathrm{B} \alpha$ by $\mathrm{E}_{2}$ may regulate the inflammatory response in eutopic and ectopic endometrial cells. Our in vivo and in vitro findings suggest that this effect of estrogen on IкB $\alpha$ may not be optimal in ectopic endometrium, which may be an important factor in the pathogenesis of endometriosis.

\section{Acknowledgement}

The authors appreciate, Özlem Guzeloglu-Kayisli PhD (Department of Obstetrics and Gynecology, College of Medicine, University of South Florida) for their scientific supporting as well as language editing of the manuscript.

\section{Ethics}

Ethics Committee Approval: The study was approved by the Human Investigation Committee of Yale University Local Ethics Committee (approval number: HIC\#22334).

Informed Consent: Consent form was filled out by all participants.

Peer-review: External and internal peer-reviewed.

\section{Authorship Contributions}

Surgical and Medical Practices: A.A., Concept: A.A., Design: A.A., Ü.A.K., Data Collection or Processing: Ü.A.K., Analysis or Interpretation: S.A., Literature Search: S.A., Writing: Ü.A.K., S.A., A.A.

Conflict of Interest: No conflict of interest was declared by the authors.
Financial Disclosure: The authors declared that this study received no financial support.

\section{References}

1. Uimari O, Rahmioglu N, Nyholt DR, Vincent K, Missmer SA, Becker $\mathrm{C}$, et al. Genome-wide genetic analyses highlight mitogenactivated protein kinase (MAPK) signaling in the pathogenesis of endometriosis. Hum Reprod 2017;32:780-93.

2. Cheng W, Chen L, Yang S, Han J, Zhai D, Ni J, et al. Puerarin suppresses proliferation of endometriotic stromal cells partly via the MAPK signaling pathway induced by 17 ss-estradiol-BSA. PLoS One 2012;7:e45529.

3. Cakmak H, Guzeloglu-Kayisli O, Kayisli UA, Arici A. Immuneendocrine interactions in endometriosis. Front Biosci (Elite Ed) 2009;1:429-43.

4. Azuma Y, Taniguchi F, Nakamura K, Nagira K, Khine YM, Kiyama $\mathrm{T}$, et al. Lipopolysaccharide promotes the development of murine endometriosis-like lesions via the nuclear factor-kappa B pathway. Am J Reprod Immunol 2017.

5. Zhu F, Liu M, Pan Y, Wang X, Chen Y. [Small hairpin RNA targeting inhibition of NF-kappaB gene in endometriosis therapy of Macaca fascicularis]. Zhonghua Fu Chan Ke Za Zhi 2015;50:48-53.

6. Alvarado-Diaz CP, Nunez MT, Devoto L, Gonzalez-Ramos R. Iron overload-modulated nuclear factor kappa-B activation in human endometrial stromal cells as a mechanism postulated in endometriosis pathogenesis. Fertil Steril 2015;103:439-47.

7. Perkins ND. Integrating cell-signalling pathways with NF-kappaB and IKK function. Nat Rev Mol Cell Biol 2007;8:49-62.

8. Gilmore TD. Introduction to NF-kappaB: players, pathways, perspectives. Oncogene. 2006;25:6680-4.

9. Sen R, Baltimore D. Multiple nuclear factors interact with the immunoglobulin enhancer sequences. Cell 1986;46:705-16.

10. Chang KK, Liu LB, Li H, Mei J, Shao J, Xie F, et al. TSLP induced by estrogen stimulates secretion of MCP-1 and IL-8 and growth of human endometrial stromal cells through JNK and NF-kappaB signal pathways. Int J Clin Exp Pathol 2014;7:1889-99.

11. Kim SH, Ihm HJ, Oh YS, Chae HD, Kim CH, Kang BM. Increased nuclear expression of nuclear factor kappa-B p65 subunit in the eutopic endometrium and ovarian endometrioma of women with advanced stage endometriosis. Am J Reprod Immunol 2013;70:497508.

12. Tian B, Brasier AR. Identification of a nuclear factor kappa B-dependent gene network. Recent Prog Horm Res 2003;58:95-130.

13. Hacker H, Karin M. Regulation and function of IKK and IKK-related kinases. Sci STKE. 2006;2006:re13.

14. McKay LI, Cidlowski JA. Molecular control of immune/inflammatory responses: interactions between nuclear factor-kappa B and steroid receptor-signaling pathways. Endocr Rev 1999;20:435-59.

15. Baeuerle PA, Baltimore D. I kappa B: a specific inhibitor of the NFkappa B transcription factor. Science 1988;242:540-6.

16. Werner SL, Barken D, Hoffmann A. Stimulus specificity of gene expression programs determined by temporal control of IKK activity. Science 2005;309:1857-61.

17. Beg AA, Finco TS, Nantermet PV, Baldwin AS. Tumor necrosis factor and interleukin-1 lead to phosphorylation and loss of I kappa B alpha: a mechanism for NF-kappa B activation. Mol Cell Biol 1993;13:3301-10.

18. Mercurio F, Zhu H, Murray BW, Shevchenko A, Bennett BL, Li J, et al. IKK-1 and IKK-2: cytokine-activated IkappaB kinases essential for NF-kappaB activation. Science 1997;278:860-6. 
19. Kim YA, Kim JY, Kim MR, Hwang KJ, Chang DY, Jeon MK. Tumor necrosis factor-alpha-induced cyclooxygenase-2 overexpression in eutopic endometrium of women with endometriosis by stromal cell culture through nuclear factor-kappaB activation. J Reprod Med 2009;54:625-30.

20. Veillat V, Lavoie $\mathrm{CH}$, Metz $\mathrm{CN}$, Roger T, Labelle Y, Akoum A. Involvement of nuclear factor-kappaB in macrophage migration inhibitory factor gene transcription up-regulation induced by interleukin- 1 beta in ectopic endometrial cells. Fertil Steril 2009;91(5 Suppl):2148-56.

21. Cao WG, Morin M, Metz C, Maheux R, Akoum A. Stimulation of macrophage migration inhibitory factor expression in endometrial stromal cells by interleukin 1, beta involving the nuclear transcription factor NFkappaB. Biol Reprod 2005;73:565-70.

22. MenendezJA, Lupu R. Fatty acid synthase regulates estrogen receptoralpha signaling in breast cancer cells. Oncogenesis 2017;6:e299.

23. Serizawa I, Iwasaki N, Ishida H, Saito SY, Ishikawa T. G-protein coupled estrogen receptor-mediated non-genomic facilitatory effect of estrogen on cooling-induced reduction of skin blood flow in mice. Eur J Pharmacol 2017;797:26-31.

24. Kayisli UA, Mahutte NG, Arici A. Uterine chemokines in reproductive physiology and pathology. Am J Reprod Immunol 2002;47:213-21.

25. Cinar O, Seval Y, Uz YH, Cakmak H, Ulukus M, Kayisli UA, et al. Differential regulation of Akt phosphorylation in endometriosis. Reprod Biomed Online 2009;19:864-71.

26. Guzeloglu-Kayisli O, Halis G, Taskiran S, Kayisli UA, Arici A. DNAbinding ability of NF-kappaB is affected differently by ERalpha and ERbeta and its activation results in inhibition of estrogen responsiveness. Reprod Sci 2008;15:493-505.

27. Deshpande R, Khalili H, Pergolizzi RG, Michael SD, Chang MD. Estradiol down-regulates LPS-induced cytokine production and NFkB activation in murine macrophages. Am J Reprod Immunol 1997;38:46-54.

28. Arici A, Senturk LM, Seli E, Bahtiyar MO, Kim G. Regulation of monocyte chemotactic protein-1 expression in human endometrial stromal cells by estrogen and progesterone. Biol Reprod 1999;61:8590.

29. Chang KK, Liu LB, Jin LP, Zhang B, Mei J, Li H, et al. IL-27 triggers IL-10 production in Th17 cells via a c-Maf/RORgammat/Blimp-1 signal to promote the progression of endometriosis. Cell Death Dis 2016;8:e2666.

30. Ahn SH, Monsanto SP, Miller C, Singh SS, Thomas R, Tayade C. Pathophysiology and Immune Dysfunction in Endometriosis. Biomed Res Int 2015;2015:795976.

31. Akoum A, Lawson C, McColl S, Villeneuve M. Ectopic endometrial cells express high concentrations of interleukin (IL)-8 in vivo regardless of the menstrual cycle phase and respond to oestradiol by up-regulating IL-1-induced IL-8 expression in vitro. Mol Hum Reprod 2001;7:859-66.

32. Sikora J, Mielczarek-Palacz A, Kondera-Anasz Z. Association of the Precursor of Interleukin-1beta and Peritoneal Inflammation-Role in Pathogenesis of Endometriosis. J Clin Lab Anal 2016;30:831-7.

33. Gogacz M, Winkler I, Bojarska-Junak A, Tabarkiewicz J, Semczuk A, Rechberger $\mathrm{T}$, et al. Increased percentage of Th17 cells in peritoneal fluid is associated with severity of endometriosis. J Reprod Immunol 2016;117:39-44.

34. Lockwood CJ, Schatz F, Krikun G. Angiogenic factors and the endometrium following long term progestin only contraception. Histol Histopathol 2004;19:167-72.

35. DeMayo FJ, Zhao B, Takamoto N, Tsai SY. Mechanisms of action of estrogen and progesterone. Ann N Y Acad Sci 2002;955:48-59; discussion 86-8,96-406.
36. Chen LH, Fan YH, Kao PY, Ho DT, Ha JC, Chu LW, et al. Genetic Polymorphisms in Estrogen Metabolic Pathway Associated with Risks of Alzheimerıs Disease: Evidence from a Southern Chinese Population. J Am Geriatr Soc 2017;65:332-9.

37. Nicks KM, Fowler TW, Gaddy D. Reproductive hormones and bone. Curr Osteoporos Rep 2010;8:60-7.

38. Gielen SC, Santegoets LA, Kuhne LC, Van Ijcken WF, Boers-Sijmons B, Hanifi-Moghaddam P, et al. Genomic and nongenomic effects of estrogen signaling in human endometrial cells: involvement of the growth factor receptor signaling downstream AKT pathway. Reprod Sci 2007; 14:646-54.

39. Li P, Xu Y, Gan Y, Wang L, Ouyang B, Zhang C, et al. Estrogen Enhances Matrix Synthesis in Nucleus Pulposus Cell through the Estrogen Receptor beta-p38 MAPK Pathway. Cell Physiol Biochem 2016;39:2216-26.

40. Zeng C, Xu JN, Zhou Y, Yang HX, Zhou YF, Xue Q. C-Jun NH2Terminal Kinase and p38 Inhibition Suppresses Prostaglandin E2Stimulated Aromatase and Estrogen Receptor Levels in Human Endometriosis. J Clin Endocrinol Metab 2015;100:E1404-14.

41. Chen W, Cui Y, Zheng S, Huang J, Li P, Simoncini T, et al. 2-methoxyestradiol induces vasodilation by stimulating $\mathrm{NO}$ release via PPARgamma/PI3K/Akt pathway. PLoS One 2015;10:e0118902.

42. Lee DH, Kim SC, Joo JK, Kim HG, Na YJ, Kwak JY, et al. Effects of 17 beta-estradiol on the release of monocyte chemotactic protein-1 and MAPK activity in monocytes stimulated with peritoneal fluid from endometriosis patients. J Obstet Gynaecol Res 2012;38:516-25.

43. Zhang L, Xiong W, Xiong Y, Liu H, Li N, Du Y, et al. Intracellular Wnt/Beta-Catenin Signaling Underlying 17beta-Estradiol-Induced Matrix Metalloproteinase 9 Expression in Human Endometriosis. Biol Reprod 2016;94:70.

44. Liu L, Wang Z. Estrogen attenuates lipopolysaccharide-induced nitric oxide production in macrophages partially via the nongenomic pathway. Cell Immunol 2013;286:53-8.

45. Aoyagi Y, Nasu K, Kai K, Hirakawa T, Okamoto M, Kawano Y, et al. Decidualization Differentially Regulates microRNA Expression in Eutopic and Ectopic Endometrial Stromal Cells. Reprod Sci 2017;24:445-55.

46. Christian M, Mak I, White JO, Brosens JJ. Mechanisms of decidualization. Reprod Biomed Online 2002;4 (Suppl 3):24-30.

47. Sahin L, Dincel O, Turk BA. Rectus abdominal muscle endometriosis in a patient with cesarian scar: case report. Clin Exp Obstet Gynecol 2013;40:599-600.

48. Lousse JC, Van Langendonckt A, Gonzalez-Ramos R, Defrere S, Renkin E, Donnez J. Increased activation of nuclear factor-kappa B (NF-kappaB) in isolated peritoneal macrophages of patients with endometriosis. Fertil Steril 2008;90:217-20.

49. Gonzalez-Ramos R, Donnez J, Defrere S, Leclercq I, Squifflet J, Lousse JC, et al. Nuclear factor-kappa B is constitutively activated in peritoneal endometriosis. Mol Hum Reprod 2007;13:503-9.

50. Zahid H, Simpson ER, Brown KA. Inflammation, dysregulated metabolism and aromatase in obesity and breast cancer. Curr Opin Pharmacol 2016;31:90-6.

51. Basar M, Yen CF, Buchwalder LF, Murk W, Huang SJ, Godlewski K, et al. Preeclampsia-related increase of interleukin-11 expression in human decidual cells. Reproduction 2010;140:605-12.

52. Li M, Carpio DF, Zheng Y, Bruzzo P, Singh V, Ouaaz F, et al. An essential role of the NF-kappa B/Toll-like receptor pathway in induction of inflammatory and tissue-repair gene expression by necrotic cells. J Immunol 2001;166:7128-35.

53. Yavuzcan A, Caglar M, Ustun Y, Dilbaz S, Ozdemir I, Yildiz E, et al. Evaluation of mean platelet volume, neutrophil/lymphocyte ratio 
and platelet/lymphocyte ratio in advanced stage endometriosis with endometrioma. J Turk Ger Gynecol Assoc 2013;14:210-5.

54. Selcuk I, Bozdag G. Recurrence of endometriosis; risk factors, mechanisms and biomarkers; review of the literature. J Turk Ger Gynecol Assoc 2013;14:98-103.

55. Malutan AM, Drugan T, Ciortea R, Bucuri C, Rada MP, Mihu D. Endometriosis-associated changes in serum levels of interferons and chemokines. Turk J Med Sci 2017;47:115-22.

56. Sun WH, Keller ET, Stebler BS, Ershler WB. Estrogen inhibits phorbol ester-induced I kappa B alpha transcription and protein degradation. Biochem Biophys Res Commun 1998;244:691-5.

57. Hsu SM, Chen YC, Jiang MC. 17 beta-estradiol inhibits tumor necrosis factor-alpha-induced nuclear factor-kappa B activation by increasing nuclear factor-kappa B p105 level in MCF-7 breast cancer cells. Biochem Biophys Res Commun 2000;279:47-52.

58. Lee EG, Mickle-Kawar BM, Reinke LA, Gallucci RM. Estrogen suppresses heptatic IkappaB expression during short-term alcohol exposure. Inflamm Res 2012;61:1053-61.

59. Bulun SE, Gurates B, Fang Z, Tamura M, Sebastian S, Zhou J, et al. Mechanisms of excessive estrogen formation in endometriosis. J Reprod Immunol 2002;55:21-33.

60. Ponce C, Torres M, Galleguillos C, Sovino H, Boric MA, Fuentes A, et al. Nuclear factor kappaB pathway and interleukin- 6 are affected in eutopic endometrium of women with endometriosis. Reproduction 2009;137:727-37.

61. Oral E, Arici A. Pathogenesis of endometriosis. Obstet Gynecol Clin North Am 1997;24:219-33.

62. Yang S, Fang Z, Suzuki T, Sasano H, Zhou J, Gurates B, et al. Regulation of aromatase P450 expression in endometriotic and endometrial stromal cells by CCAAT/enhancer binding proteins (C/EBPs): decreased C/EBPbeta in endometriosis is associated with overexpression of aromatase. J Clin Endocrinol Metab 2002;87:233645.

63. Qu J, Zhu Y, Wu X, Zheng J, Hou Z, Cui Y, et al. Smad3/4 Binding to Promoter II of P450arom So As to Regulate Aromatase Expression in Endometriosis. Reprod Sci 2016.

64. Sanchez AM, Somigliana E, Vercellini P, Pagliardini L, Candiani M, Vigano P. Endometriosis as a detrimental condition for granulosa cell steroidogenesis and development: From molecular alterations to clinical impact. J Steroid Biochem Mol Biol 2016;155:35-46.

65. Sakamoto Y, Harada T, Horie S, Iba Y, Taniguchi F, Yoshida S, et al. Tumor necrosis factor-alpha-induced interleukin-8 (IL8) expression in endometriotic stromal cells, probably through nuclear factor-kappa B activation: gonadotropin-releasing hormone agonist treatment reduced IL-8 expression. J Clin Endocrinol Metab 2003;88:730-5.

66. Akoum A, Lemay A, Maheux R. Estradiol and interleukin-lbeta exert a synergistic stimulatory effect on the expression of the chemokine regulated upon activation, normal $\mathrm{T}$ cell expressed, and secreted in endometriotic cells. J Clin Endocrinol Metab 2002;87:5785-92.

67. Page M, Tuckerman EM, Li TC, Laird SM. Expression of nuclear factor kappa B components in human endometrium. J Reprod Immunol 2002;54:1-13.

68. King AE, Critchley HO, Kelly RW. The NF-kappaB pathway in human endometrium and first trimester decidua. Mol Hum Reprod 2001;7:175-83. 